\title{
Influence of sample storage duration on serum protein profiles assessed by surface-enhanced laser desorption/ ionisation time-of-flight mass spectrometry (SELDI-TOF MS)
}

\author{
Marie-Christine W. Gast ${ }^{1, *}$, Carla H. van Gils ${ }^{2}$, \\ Lodewijk F.A. Wessels ${ }^{3,4}$, Nathan Harris ${ }^{5}$, \\ Johannes M.G. Bonfrer ${ }^{6}$, Emiel J.Th. Rutgers ${ }^{7}$, \\ Jan H.M. Schellens ${ }^{8,9}$ and Jos H. Beijnen ${ }^{1,9}$ \\ ${ }^{1}$ Department of Pharmacy and Pharmacology, The \\ Netherlands Cancer Institute/Slotervaart Hospital, \\ Amsterdam, The Netherlands \\ 2 Julius Center for Health Sciences and Primary \\ Care, University Medical Center Utrecht, Utrecht, \\ The Netherlands \\ ${ }^{3}$ Bioinformatics and Statistics, Department of \\ Molecular Biology, The Netherlands Cancer Institute, \\ Amsterdam, The Netherlands \\ ${ }^{4}$ Faculty of EEMCS, Technical University Delft, Delft, \\ The Netherlands \\ ${ }^{5}$ Vermillion Inc., Fremont, CA, USA \\ ${ }^{6}$ General Clinical Laboratory, Antoni van \\ Leeuwenhoek Hospital, Amsterdam, The \\ Netherlands \\ ${ }^{7}$ Department of Surgery, The Netherlands Cancer \\ Institute/Antoni van Leeuwenhoek Hospital, \\ Amsterdam, The Netherlands \\ ${ }^{8}$ Department of Clinical Oncology, Division of \\ Medical Oncology, The Netherlands Cancer Institute/ \\ Antoni van Leeuwenhoek Hospital, Amsterdam, The \\ Netherlands \\ ${ }^{9}$ Faculty of Science, Department of Pharmaceutical \\ Sciences, Division of Biomedical Analysis, Utrecht \\ University, Utrecht, The Netherlands
}

\footnotetext{
Abstract

Background: Issues have been raised concerning the robustness and validity of alleged serum markers discovered by surface-enhanced laser desorption/ionisation time-of-flight mass spectrometry (SELDI-TOF MS). Pre-analytical variables have been shown to exert a profound effect on protein profiles, irrespective of true biological variation. However, little is known about the possible effects of sample storage duration on protein profiles. We, therefore, aimed to investigate the effects of extended storage duration on the serum protein profile.

Methods: Archival sera from 140 breast cancer patients, stored at $-30^{\circ} \mathrm{C}$ for $1-11$ years, were profiled

*Corresponding author: Ms. Marie-Christine Gast, Slotervaart Hospital, Department of Pharmacy and Pharmacology, P.O. Box 90440, 1006 BK Amsterdam, The Netherlands

Phone: +31-20-512 5088, Fax: +31-20-512 4753,

E-mail: Marie-Christine.Gast@slz.nl

Received November 25, 2008; accepted March 5, 2009; previously published online May 6, 2009
}

by SELDI-TOF MS using immobilised metal affinity capture (IMAC) arrays, a condition applied in the majority of breast cancer biomarker discovery studies.

Results: Fourteen peak clusters, structurally identified as C3a des-arginine anaphylatoxin and multiple fragments of albumin and fibrinogen, were found to be significantly associated with sample storage duration by five distinct patterns. These proteins have been described previously as potential cancer markers, rendering them specific to both disease and sample handling issues.

Conclusions: To prevent experimental variation being interpreted erroneously as disease associated variation, assessment of potential confounding pre-analytical parameters is a pre-requisite in biomarker discovery and validation studies. In addition, with respect to the different (non-)linear patterns observed in the current study, simply performing linear corrections to account for sample storage duration will not necessarily suffice.

Clin Chem Lab Med 2009;47:694-705.

Keywords: pre-analytical parameters; proteomics; serum protein profiling; storage duration; surfaceenhanced laser desorption/ionisation time-of-flight mass spectrometry (SELDI-TOF MS).

\section{Introduction}

In the last two decades, much effort has been devoted to the search for improved markers that can be applied in screening, diagnosis and prognosis of cancer. Genetic markers for cancer were initially pursued by the investigation of the cancer genome. However, it is currently understood that gene analysis by itself provides an incomplete picture. Alternative splicing of both mRNA and proteins, combined with more than 100 unique post-translational modifications, can result in one gene giving rise to multiple protein species (1). Thus, compared to the genome, the proteome can provide a more dynamic and accurate reflection of both the intrinsic genetic programme of the cell and the impact of its immediate environment (2). Since proteome analysis can provide the link between gene sequence and cellular physiology (3), proteomics is expected to complement gene analyses for the detection of novel cancer markers (4).

Several different methods based on mass spectrometry (MS) have been applied to interrogate the proteome. One of the technologies used extensively for protein profiling is surface-enhanced laser desorp- 
tion/ionisation time-of-flight mass spectrometry (SELDI-TOF MS) (5). This technology combines retentive chromatography with laser desorption/ionisation MS instrumentation, enabling high-throughput mass profiling of highly complex biological samples such as serum. Spectral patterns are compared across sample groups to find discerning masses or differential changes in peak intensities.

The majority of SELDI studies reported thus far have evaluated serum, although the technology is equally effective in analysing e.g., tissue lysates (6). Serum is an easy to sample protein-rich body fluid perfusing all tissues of the body and thus, theoretically, provides a good reflection of the human proteome (7). In addition, existing serum banks could readily provide serum from a large number of patients allowing studies to be completed in a more timely manner (8). Many reports have described the successful application of SELDI-TOF MS in the discovery of potential serum markers for different types of cancer, such as ovarian (9), colorectal (10), and thyroid carcinoma (11). Issues, however, have been raised concerning the robustness and validity of alleged serum markers discovered by SELDI-TOF MS. A potential drawback of analysing high-dimensional proteomic (SELDI-TOF MS) data for disease-associated biomarkers is the propensity to discover patterns resulting from pre-analytical artifacts in a given sample set, rather than from the pathology of interest (12). Several lines of evidence indicate that pre-analytical variables, such as sample collection, processing and storage temperature can exert a profound effect on protein profiles, regardless of the true biological variation (13-15). Little is known about the possible effects of the pre-analytical variable of sample storage duration on the serum proteome. Although this parameter has been investigated in two studies, only very few sera $(n \leq 12)$, stored for relatively short periods of time $(1-3$ months) were profiled $(16,17)$. Clinical studies generally exceed these storage durations, since study sera either originate from sample banks (18-20), or were collected prospectively over a period of years (21). We have previously investigated the effects of long-term storage (0-16 months) using a larger sample size $(n=150)$ (22). However, even this extended storage interval is usually exceeded by clinical proteomics studies. For example, McLerran et al. (23) reported a storage interval of more than 20 years. Following analysis of prospectively collected sera, their initial results obtained using archival sera could not be confirmed. After they subjected their initial study to extensive post-study data analysis, they discovered their study to be biased by sample storage duration, as one confounding variable. Their study of prostate cancer provides a clear example of the potentially detrimental effects of this long-term storage duration on clinical proteomics studies.

Although the study of McLerran is not unique in analysing sera originating from a serum bank, the influence of storage duration on serum protein profiles is seldomly investigated. We, therefore, investigated the effects of extended storage duration of
1-11 years on the serum protein profile. We evaluated archival sera from 140 breast cancer patients using SELDI-TOF MS with immobilised metal affinity capture (IMAC30) arrays. We employed these settings as they are commonly used in serum biomarker discovery studies performed in breast cancer $(18,19$, 21, 24-28). Peak clusters that were found to be significantly associated with sample storage duration were structurally identified.

\section{Materials and methods}

\section{Study population}

Archival sera from 140 breast cancer patients, collected between January 1993 and December 2002, were analysed in our laboratory using standard analytical procedures. All samples originated from the Netherlands Cancer Institute serum bank. Samples were collected prior to therapy after obtaining informed consent and approval by the Institutional Review Board. Samples were collected into Venoject ${ }^{\circledR}$ serum tubes (Terumo Europe, Leuven, Belgium). After collection, blood was allowed to coagulate for $30 \mathrm{~min}$, and then centrifuged at room temperature for $10 \mathrm{~min}$ at $1700 \mathrm{~g}$. Serum was transferred into 1.8-mL polypropylene screw cap tubes

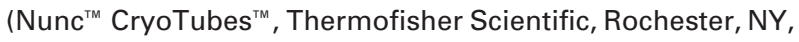
USA) and stored frozen at $-30^{\circ} \mathrm{C}$ from 9 to 128 months until analysis.

\section{Chemicals}

All chemicals were obtained from Sigma (St. Louis, MO, USA), unless stated otherwise.

\section{Serum protein profiling}

Serum protein profiling was performed using the ProteinChip SELDI Reader (Bio-Rad Labs, Hercules, CA, USA) with IMAC30 arrays. Sera were analysed in three batches of 39, 47 , and 54 samples on three consecutive days. Throughout the assay, arrays were assembled in a 96-well bioprocessor which was shaken on a platform shaker at $350 \mathrm{rpm}$. Arrays were charged twice with $50 \mu \mathrm{L} 100 \mathrm{mM}$ nickel sulphate (Merck, Darmstadt, Germany) for 15 min, followed by three rinses with deionised water (Braun, Emmenbrücke, Germany) and two equilibrations with $200 \mu \mathrm{L}$ phosphate buffered saline (PBS; $0.01 \mathrm{M}$ ) pH 7.4/0.5 M sodium chloride/0.1\% TritonX-100 (binding buffer; sodium chloride from Merck) for $5 \mathrm{~min}$. Sera were thawed on ice and denatured using a 1:10 dilution in $9 \mathrm{M}$ urea/2\% 3-[(3-cholamidopropyl)dimethylammonio-]-1-propanesulfonic acid (CHAPS). Pre-treated samples were diluted 1:10 in binding buffer and randomly applied in singlicate to the arrays. After a 30-min incubation the arrays were washed 2 times with binding buffer and twice with PBS pH 7.4/0.5 M sodium chloride for $5 \mathrm{~min}$. Following a quick rinse with deionised water, arrays were airdried. A saturated solution of sinapinic acid (Bio-Rad Labs) in $50 \%$ acetonitrile (ACN; Biosolve, Valkenswaard, The Netherlands) $/ 0.5 \%$ trifluoroacetic acid (TFA; Merck) was applied twice $(0.6 \mu \mathrm{L})$ to the arrays as the matrix. Following air-drying, the arrays were analysed using the ProteinChip SELDI (PBSIlc) Reader. Data were collected between 0 and $100 \mathrm{kDa}$, averaging 65 laser shots with intensity 200 , detector sensitivity 9 , and a focus lag time of $636 \mathrm{~ns}(\mathrm{~m} / \mathrm{z} 7000)$. For mass accuracy, the instrument was calibrated on the day of measurements with all-in-one peptide standard (Bio-Rad Labs). 


\section{Statistics and bioinformatics}

Spectra of the three batches were processed separately by the ProteinChip Software v3.1 (Bio-Rad Labs). Spectra were baseline subtracted, and then normalised to the total ion current. Spectra with normalisation factors $>2$ or $<0.5$ were excluded from further analysis.

Following pre-processing of the spectra, the Biomarker Wizard (BMW) software package was used for peak detection. Peaks were auto-detected when they occurred in at least $30 \%$ of spectra and had a signal-to-noise ratio $(\mathrm{S} / \mathrm{N})$ of at least 7. Peak clusters were completed by peaks with a $\mathrm{S} / \mathrm{N}$ of at least 5 in a cluster mass window of $0.4 \%$. Peak information was exported as spreadsheet files. The batches were analysed on three consecutive days, a parameter which can influence spectral data $(29,30)$. Merging peak intensity data from the three sets would likely lead to spurious results. Thus, the intensities of peaks occurring across all three sample sets were log transformed per sample set to obtain normal distributions. The log transformed peak intensities were then converted to standard Z-value scores for each sample set. This was accomplished by subtracting the mean and dividing by the SD. The log-Z transformed data of the three sets were merged in one file.

To investigate the effect of sample storage time on peak expression, samples were split into four categories of differing duration of sample storage $(\leq 32$ months, $n=16$; 32-64 months, $\mathrm{n}=59$; 64-96 months, $\mathrm{n}=48$; $>96$ months, $n=17$ ). Mean peak intensity differences between each of the four categories were evaluated using ANOVA. We corrected $p$-values for multiple testing using Bonferroni correction. We performed this correction by multiplying the $p$-values with the number of peak clusters detected $(n=76)$. We also investigated the relationship between peak intensity and sample storage time as a function of patients' age and/or stage of disease. We accomplished this by dividing the samples into age-specific tertiles $(\leq 49.4,49.5-61.8$, and $>61.8$ years $)$, or according to the stage of disease (Stage $2 \mathrm{~A}$ or $2 \mathrm{~B}$ ). Mean peak intensity differences between age-specific tertiles were investigated using ANOVA and the t-test was used to evaluate differences with respect to stage of disease. Time-associated clusters that were significantly related to patients' age and/or stage of disease were further investigated. The relationship between peak intensity and storage duration was investigated in subgroups of age (i.e., $<$ or $>$ median age) and stage (i.e., Stage $2 \mathrm{~A}$ or $2 \mathrm{~B}$ ). Statistical analyses were performed using SPSS statistical software, version 13.0 (SPSS Inc., Chicago, IL, USA).

\section{Protein purification and identification}

Five hundred microliter of serum, containing the proteins significantly associated with sample storage duration, was denatured in $9 \mathrm{M}$ urea/2\% CHAPS/50 mM Tris- $\mathrm{HCl} \mathrm{pH} 9$. The sample was then fractionated on $\mathrm{Q}$ Ceramic HyperD beads with a strong anion exchange moiety (Biosepra Inc., Malborough, MA, USA). The flow-through was collected, and bound proteins were eluted using buffers with $\mathrm{pH}$ from 9 to 3. The fractions containing proteins of interest were further purified by size fractionation using Microcon $50 \mathrm{kDa} \mathrm{MW}$ spin concentrators (YM50, Millipore, Billerica, MA, USA) with increasing concentrations of ACN/TFA $0.1 \%$. The filtrates containing the proteins of interest were de-salted by application on reversed phase RP18 beads (Varian Inc., Palo Alto, CA, USA), followed by elution with increasing concentrations of ACN/TFA $0.1 \%$. The purification process was monitored by profiling each fraction on IMAC30 $\mathrm{Ni}$ arrays and NP20 arrays; a non-selective, silica chromatographic surface.
Eluates containing the proteins of interest were dried and redissolved in loading buffer for sodium dodecylsulfate-polyacrylamide gel electrophoresis (SDS-PAGE). Gel electrophoresis was performed on Novex NuPage gels (18\% TrisGlycine gel; Invitrogen, San Diego, CA, USA). Following staining with colloidal Coomassie stain (Simply Blue; Invitrogen), protein bands of interest were excised and collected. The proteins within the excised bands were eluted by washing twice with $30 \% \mathrm{ACN} / 100 \mathrm{mM}$ ammonium bicarbonate, followed by dehydration in $100 \%$ ACN. Next, gel bands were heated at $50^{\circ} \mathrm{C}$ for $5 \mathrm{~min}$ and eluted with $45 \%$ formic acid/ $30 \% \mathrm{ACN} / 10 \%$ isopropanol under sonification for $30 \mathrm{~min}$. The eluates were left overnight at room temperature and dried the following day. They were then re-suspended in $20 \mathrm{ng} / \mu \mathrm{L}$ trypsin (Promega, Madison, WI, USA) in 10\% ACN/ $25 \mathrm{mM}$ ammonium bicarbonate, followed by incubation at room temperature for $4 \mathrm{~h}$. The tryptic digests were profiled on NP20 chips, using $1 \mu \mathrm{L} 20 \% \alpha$-cyano-4-hydroxy cinnaminic acid (Bio-Rad Labs) in $50 \%$ ACN/0.5\% TFA as matrix. Peptides in the digests were investigated with the NCBI database using the ProFound search engine at http:// prowl.rockefeller.edu/prowl-cgi/profound.exe. We used the following search parameters: standard cleavage rules for trypsin, one missed cleavage allowed. Confirmation of protein identity was provided by sequencing tryptic digest peptides by quadrupole-TOF (Q-TOF) MS (Applied Biosystems/ MSD Sciex, Foster City, CA, USA) fitted with a ProteinChip Interface (PCl-1000). Fragment ion spectra resulting from QTOF analyses were used to search the SwissProt 44.2 database (Homo Sapiens: 11,072 sequences) with the MASCOT search engine at www.matrixscience.com (Matrix Science Ltd., London, UK). We used the following search parameters: monoisotopic precursor mass tolerance: $40 \mathrm{ppm}$, fragment mass tolerance: $0.2 \mathrm{Da}$, variable modifications: methionine oxidation, and trypsin cleavage site. Further confirmation of protein identity was performed by immunoassay on Protein $A$ beads using the appropriate antibodies. Beads were loaded with antibody in PBS, washed twice with PBS, incubated for $30 \mathrm{~min}$ with whole serum, and then washed 5 times with PBS and once with deionised water. Bound proteins were subsequently eluted using $0.1 \mathrm{M}$ acetic acid, and eluates were profiled on NP20 arrays. The extent of non-specific binding was tested using a murine IgG antibody (BioRad Labs). For all identification experiments, a serum sample lacking the protein of interest was run concurrently as a negative control.

\section{Results}

\section{Study population}

Demographics of patients and samples are summarised in Table 1. Greater than $80 \%$ of patients with breast cancer were diagnosed with Stage $2 \mathrm{~A}$ and Stage 2B invasive ductal carcinoma (IDC). The median age of patients was 52.6 years.

\section{Serum protein profiling}

Representative SELDI-TOF MS spectra are presented in Figure 1. Following serum protein profiling and spectrum pre-processing by the ProteinChip Software v3.1, spectra of two breast cancer patients from batch three were discarded due to aberrant normalisation factors. The BMW detected a total of 76 peak clusters across the spectra of all three batches. 
Table 1 Demographics of the study population.

\begin{tabular}{ll}
\hline Parameter & Patients \\
\hline $\mathrm{n}$ & 140 \\
Age (years), median [IOR] $^{\text {Stage }}{ }^{\mathrm{a}}$ & $52.6[45.7-66.0]$ \\
2A & 48 \\
$2 \mathrm{~B}$ & 78 \\
3A & 10 \\
Unknown & 4 \\
Diagnosis & \\
IDC & 104 \\
ILC & 23 \\
IDC and ILC & 4 \\
Other & 9 \\
Sample storage time (months), & $61.3[49.1-76.4]$ \\
median [IQR] & \\
Sample collection interval & January 1993-December \\
& 2002 \\
\hline
\end{tabular}

aPathologically determined stage and diagnosis. IQR, interquartile range; IDC, invasive ductal carcinoma; ILC, invasive lobular carcinoma; other, mucinous, tubular, mixed, unknown.

\section{Influence of sample storage duration on the serum protein profile}

Mean log-Z peak intensity differences between the four categories of sample storage times were investigated using ANOVA. In total, 14 of the 76 peak clusters detected spectrum-wide were found to differ significantly in mean log-Z intensity between the four categories of sample storage time (Table 2). None of the 14 peak clusters were related to patients' age (ANOVA; $p>0.05$ ) or stage of disease (t-test; $p>0.05$ ).

Five different patterns by which peak intensities were associated with sample storage duration were observed. These patterns (A-E) are depicted for five representative peak clusters and shown in Figure 2. For the peak clusters m/z 2773, 2789, 3089, and 3104, a positive association with storage time was observed up to duration of storage of $\sim 5$ years. After $\sim 5$ years of storage, peak intensities gradually decreased with time (Pattern A). Peak intensities of $\mathrm{m} / \mathrm{z} 4215,5908$, 5929,6114 , and 11,091 were observed to continuously

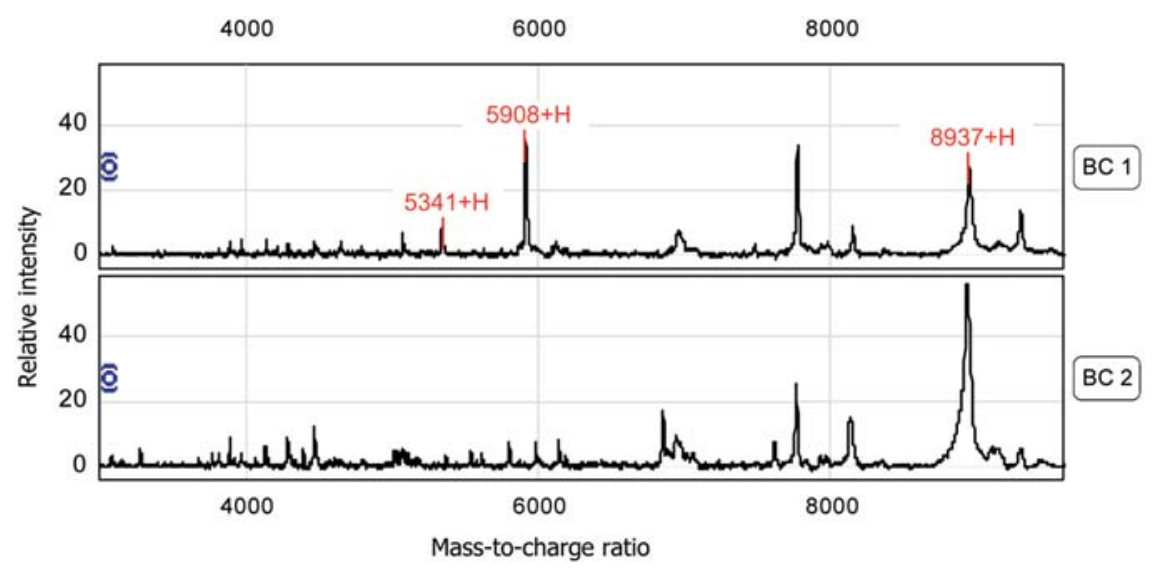

Figure 1 Example of protein profiles from sera of two patients with breast cancer stored for 10 (BC 1) and 120 (BC 2) months.

Table 2 Peak cluster information of the 14 peaks found significantly associated with sample storage duration.

\begin{tabular}{|c|c|c|c|c|}
\hline Protein & $\begin{array}{l}\text { Peak, } \\
\mathrm{m} / \mathrm{z}\end{array}$ & $\begin{array}{l}\text { ANOVA, } \\
\text { p-value }\end{array}$ & $\begin{array}{l}\text { Regulation }{ }^{\mathrm{b}} \text {, } \\
\text { pattern }\end{array}$ & (Alleged) identity ${ }^{c}$ \\
\hline \multirow[t]{4}{*}{ Albumin } & 2773 & 0.033 & A & $\mathrm{m} / \mathrm{z} 2756$ albumin $_{25-48} \mathrm{~b}+\mathrm{O}$ \\
\hline & 2789 & 0.001 & A & $\mathrm{m} / \mathrm{z} 2756$ albumin $25-48^{\mathrm{b}}+(\mathrm{O})_{2}$ \\
\hline & 3089 & 0.016 & $A$ & $\mathrm{~m} / \mathrm{z} 3089$ albumin $_{25-51}{ }^{\mathrm{b}}$ \\
\hline & 3104 & 0.005 & $A$ & $\mathrm{~m} / \mathrm{z} 3089$ albumin $_{25-51}{ }^{\mathrm{b}}+\mathrm{O}$ \\
\hline \multirow[t]{7}{*}{ Fibrinogen } & 4215 & $<0.001$ & $\mathrm{~B}$ & Unknown fibrinogen fragment \\
\hline & 5341 & 0.003 & $\mathrm{E}$ & $\mathrm{m} / \mathrm{z} 5341$ fibrinogen $_{576-625} \mathrm{~b}^{-}$ \\
\hline & 5357 & 0.046 & $E$ & $\mathrm{~m} / \mathrm{z} 5341$ fibrinogen $_{576-625}{ }^{\mathrm{b}}+0$ \\
\hline & 5908 & $<0.001$ & B & $\mathrm{m} / \mathrm{z} 5908$ fibrinogen $_{576-630^{\mathrm{b}}}$ \\
\hline & 5929 & $<0.001$ & $\mathrm{~B}$ & $\mathrm{~m} / \mathrm{z} 5908$ fibrinogen $_{576-630^{b}}+0$ \\
\hline & 6114 & 0.013 & $\mathrm{~B}$ & $\mathrm{~m} / \mathrm{z} 5908$ fibrinogen $_{576-630^{\mathrm{b}}}$ SPA adduct \\
\hline & 11,091 & 0.003 & B & Unknown fibrinogen fragment \\
\hline \multirow[t]{2}{*}{ C3a $\mathrm{a}_{\text {desArg }}$} & 4471 & 0.018 & $\mathrm{D}$ & $\mathrm{m} / \mathrm{z} 8939 \mathrm{C} 3 \mathrm{a}_{\text {desArg } 672-747^{\mathrm{b}}}$ double charge \\
\hline & 8937 & 0.002 & $\mathrm{D}$ & $\mathrm{m} / \mathrm{z} 8939 \mathrm{C} \mathrm{a}_{\text {desArg } 672-747} \mathrm{~b}$ \\
\hline Unknown & 4441 & 0.028 & $\mathrm{C}$ & Unknown \\
\hline
\end{tabular}

${ }^{a}$ Bonferroni corrected $\mathrm{p}$-values from ANOVA test of mean intensity differences between the discrete time intervals; ${ }^{b} 5$ patterns by which peak intensity was associated to sample storage duration: $A$, initial increase, followed by a gradual decrease; $B$, continuous decrease; or C, continuous increase; D, initial increase, after which intensities remain stable; and E, stable up to $\sim 8$ years of storage time, followed by a decrease. "Peptides were structurally identified. 

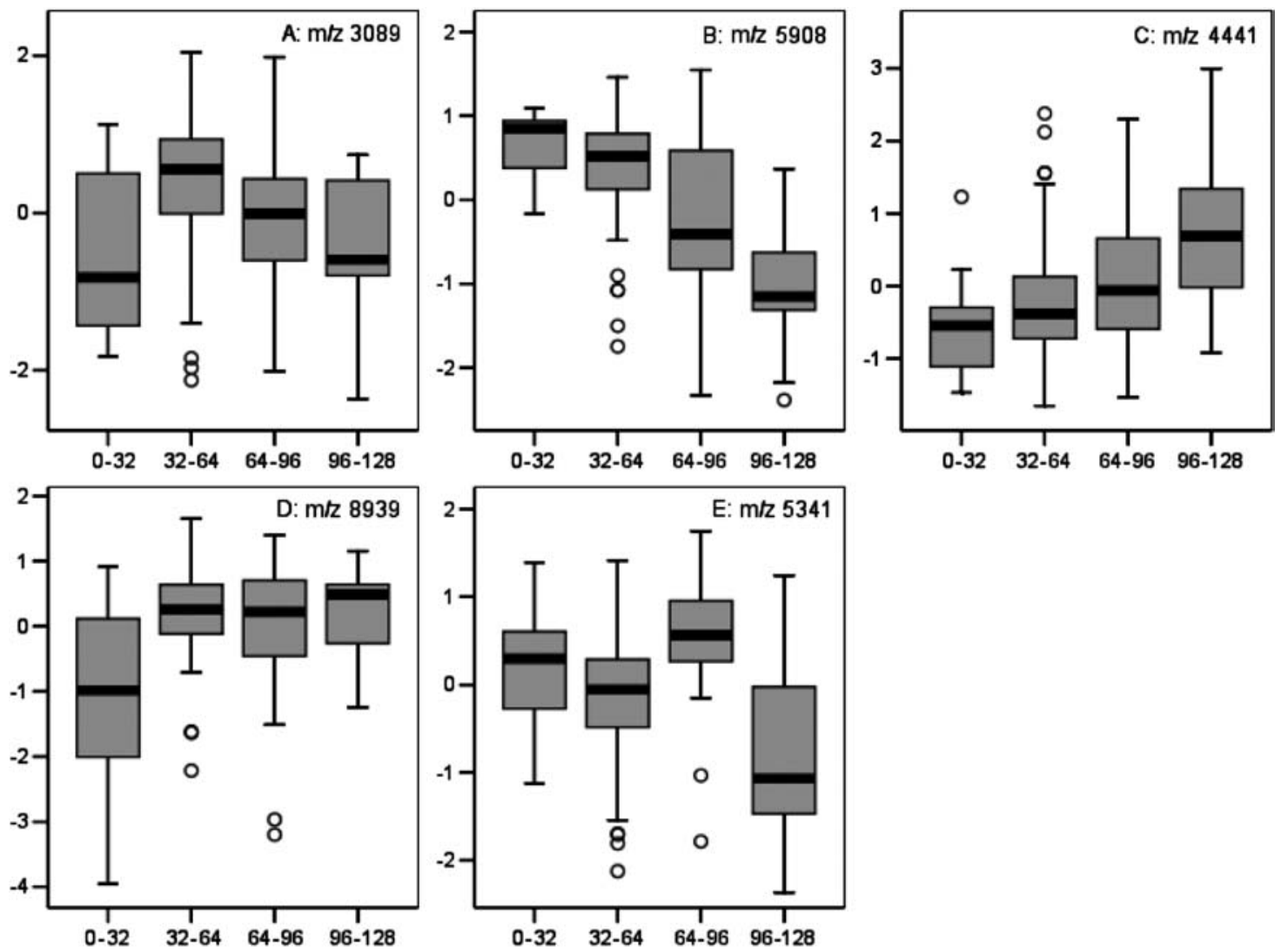

Figure 2 Representative examples of the five patterns (A-E) where peak intensities were associated with sample storage duration (y-axis: Z-log transformed peak intensity, x-axis: sample storage duration in months).

decrease during sample storage time (Pattern B), while the intensity of $\mathrm{m} / \mathrm{z} 4441$ was found to increase over time (Pattern C). The fourth pattern (Pattern D), observed in peak clusters $\mathrm{m} / \mathrm{z} 4471$, and m/z 8939, showed an initial increase in peak intensity, after which the intensities remained stable during prolonged storage. Finally, for clusters m/z 5341 and $\mathrm{m} / \mathrm{z} 5357$, peak intensities were stable up to $\sim 8$ years of storage, after which peak intensities decreased rapidly (Pattern E).

\section{Peptide purification and (tentative) identification}

The m/z 2756 and m/z 3089 peptides were present in the $\mathrm{pH} 4$ eluate after QhyperD fractionation of whole serum. Following concentration of this fraction with YM50 spin concentrators, the two peptides were detected in the $50 \%$ ACN eluate. Since the peptides were lost during the subsequent purification processes, their amino acid (aa) sequence was determined by direct tandem MS on a PCl-interfaced Q-TOF. These two peptides were identified as $\mathrm{N}$-terminal fragments of albumin (Figure 3 ). The theoretical mass of the $\mathrm{m} / \mathrm{z} 2756$ peptide ( 24 aa) and the m/z 3089 peptide (27 aa) is $2754.10 \mathrm{Da}$ and $3085.51 \mathrm{Da}$, respectively. The pl of both fragments was 6.04 .

Figure 4 depicts the correlation matrix presenting the absolute Pearson's correlation coefficients calculated for the peak intensities of the 14 peaks found to be significantly associated with storage time. The three peak clusters m/z 2756, 2773, and 2789 were found highly correlated (Figure 4). Since the mass deviation between $\mathrm{m} / \mathrm{z} 2773,2789$ and 2756 is $\sim 16$ and $32 \mathrm{Da}$, these peptides most likely represent oxidised forms of the m/z 2756 albumin fragment. Similarly, m/z 3104 was found to be highly correlated to $\mathrm{m} / \mathrm{z} 3089$ (Figure 4). Regarding the mass difference of $\sim 16 \mathrm{Da}, \mathrm{m} / \mathrm{z} 3104$ is likely to represent the oxidised form of the $\mathrm{m} / \mathrm{z} 3089$ albumin fragment. The presumed identities are supported by the observation that all five peak clusters show a similar correlation with sample storage time; an initial increase, followed by a gradual decrease in peak intensity (Pattern A).

Following QhyperD fractionation, the m/z 5908 peptide was detected in the flow-through. After concentration of this fraction with YM50 spin concentrators, the peptide was found in the flow-through. De-salting with RP18 beads resulted in elution of the peptide in the $50 \%$ ACN $/ 0.1 \%$ TFA eluate. This fraction was again concentrated with YM3 spin concentrators. Profiling of the retentate revealed only peptides $<5908 \mathrm{Da}$. In prior identification attempts, the $\mathrm{m} / \mathrm{z} 5908$ peptide was shown to degrade with increasing manipulation. The detected peptides are therefore likely originating from breakdown of the $\mathrm{m} / \mathrm{z} 5908$ peptide. Direct sequencing of three peptides by tandem MS on a QTOF confirmed the peptides to originate from a fibrinogen alpha-E fragment $\left(\mathrm{FGA}_{576-630}\right), 54$ aa in length, with a theoretical mass of 5904.22 Da and pl of 8.07 (Figure 5). 


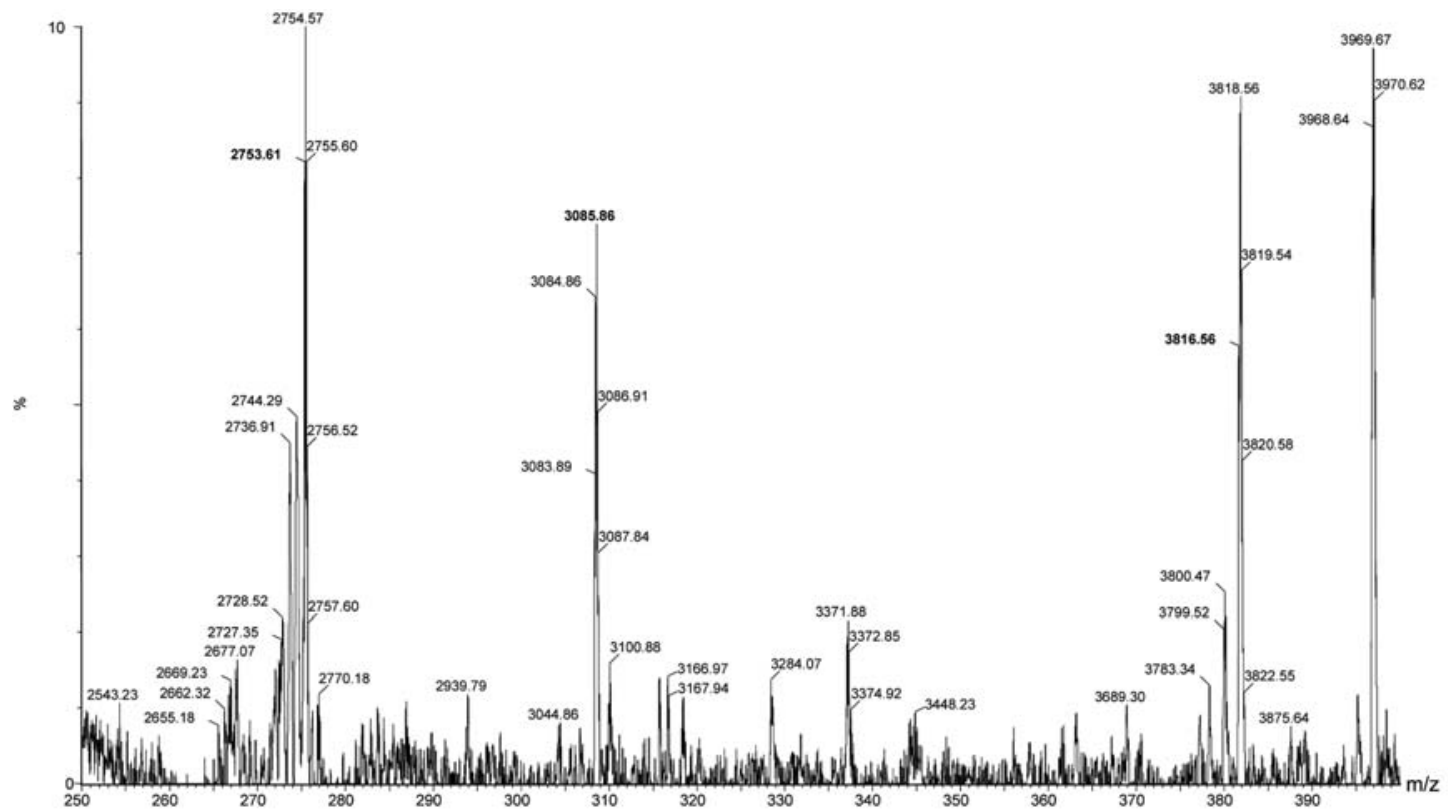

MASCOT peptide mapping results: $\quad \mathrm{m} / \mathrm{z} 2756$ and $\mathrm{m} / \mathrm{z} 3089 \mathrm{~N}$-terminal truncated albumin fragments

\begin{tabular}{llllll}
\hline $\begin{array}{l}\text { Start- } \\
\text { End }\end{array}$ & $\begin{array}{l}\text { Mr } \\
\text { (obs) }\end{array}$ & $\begin{array}{l}\text { Mr } \\
\text { (expt) }\end{array}$ & $\begin{array}{l}\text { Mr } \\
\text { (calc) }\end{array}$ & Delta & Sequence \\
\hline $25-48$ & 2753.61 & 2752.60 & 2752.43 & 0.17 & R.DAHKSEVAHRFKDLGEENFKALVL.I \\
$25-51$ & 3083.83 & 3082.82 & 3083.62 & -0.80 & R.DAHKSEVAHRFKDLGEENFKALVLIAF.A \\
\hline \multicolumn{7}{l}{ Amino acid sequence of N-terminal truncated albumin fragments (start: 25 - end: 57, 100\% sequence coverage): } \\
\multicolumn{7}{l}{ DAHKSE VAHRFKDLGE ENFKALVLIA FAQYLQQ } \\
\hline
\end{tabular}

Figure 3 Structural identification of the $\mathrm{m} / \mathrm{z} 2756$ and $\mathrm{m} / \mathrm{z} 3089$ peak clusters.

Direct sequencing of the m/z 2756 and m/z 3089 peak clusters. MS spectrum of the YM50 50\% ACN eluate. All peptides were sequenced with tandem MS using Q-TOF. Results from the MASCOT search for protein identification include start and end positions of the peptide sequence starting from the amino acid terminal of the whole protein, the observed $\mathrm{m} / \mathrm{z}$ [Mr (obs)], transformed to its experimental mass [ $\mathrm{Mr}$ (expt)], the calculated mass [ $\mathrm{Mr}$ (calc)] from the matched peptide sequence, their mass difference (Delta), and the peptide sequence (in grey: the amino acid sequence determined by Q-TOF MS).

The $\mathrm{m} / \mathrm{z} 4215,5341,5357,5908,5929,6114$ and 11,091 peak clusters were found to be highly correlated with each other (Figure 4). Also, as the mass of the $\mathrm{m} / \mathrm{z} 5341$ corresponds to the theoretical mass of the 49 aa fibrinogen alpha-E fragment $F_{G A} A_{576-625}$, the correlated peptides most likely represent oxidised fibrinogen fragments. The $\mathrm{m} / \mathrm{z} 6114$ cluster represents the SPA adduct of $\mathrm{m} / \mathrm{z} 5908 \mathrm{FGA}_{576-630}$. Except for $\mathrm{m} / \mathrm{z} 5341$ and $\mathrm{m} / \mathrm{z} 5357$, the (hypothesised) fibrinogen fragments all show similar correlation with sample storage time; gradual decrease in peak intensity over sample storage time (Pattern B).

Following QhyperD fractionation, the $\mathrm{m} / \mathrm{z} 8939$ peptide was detected in the flow-through. This fraction was concentrated using YM50 spin concentrators. The peptide was found in the $30 \% \mathrm{ACN}$ eluate. De-salting of the eluate with RP18 beads resulted in elution of the peptide in the $50 \%$ ACN $/ 0.1 \%$ TFA eluate. This was then subjected to SDS-PAGE analysis. After staining, a band in the $8.9 \mathrm{kDa}$ region was visible. This band was excised and subjected to passive elution followed by tryptic digestion of the eluate. Profiling of the geleluate confirmed the presence of the peptide. Peptide mapping of the tryptic digest identified it as complement component 3 precursor with an estimated Z- score of $1.57,4 \%$ sequence coverage. Amino acid sequencing of six peptides in the tryptic digest by tandem MS on a Q-TOF identified the marker as C3a des-arginine anaphylatoxin $\left(\mathrm{C} 3 \mathrm{a}_{\text {desArg }}, 61 \%\right.$ sequence coverage), a 76 amino acid protein with theoretical mass 8939.46 Da and pl 9.54 (Figure 6). This identity was confirmed by immunoassay using a C3a polyclonal antibody (Abcam Ltd., Cambridge, UK). Profiling of the eluates revealed the presence of a peak at $\mathrm{m} / \mathrm{z}$ 8940 . Non-specific binding, determined by binding to murine IgG antibody, was very low.

The peak intensities of $\mathrm{m} / \mathrm{z} 4471$ and $\mathrm{m} / \mathrm{z} 8939$ were highly correlated (Figure 4). From its mass, the $\mathrm{m} / \mathrm{z}$ 4471 peak most likely represents the doubly charged form of the $\mathrm{m} / \mathrm{z} 8939$ peak. The two peak clusters show a similar correlation to sample storage duration; an initial increase, after which peak intensities remain stable over time (Pattern D). This finding helps confirm our hypothesis on the identity of $\mathrm{m} / \mathrm{z} 4471$.

\section{Discussion}

We studied archival sera from 140 patients with breast cancer, stored at $-30^{\circ} \mathrm{C}$ from 1 to 11 years, 


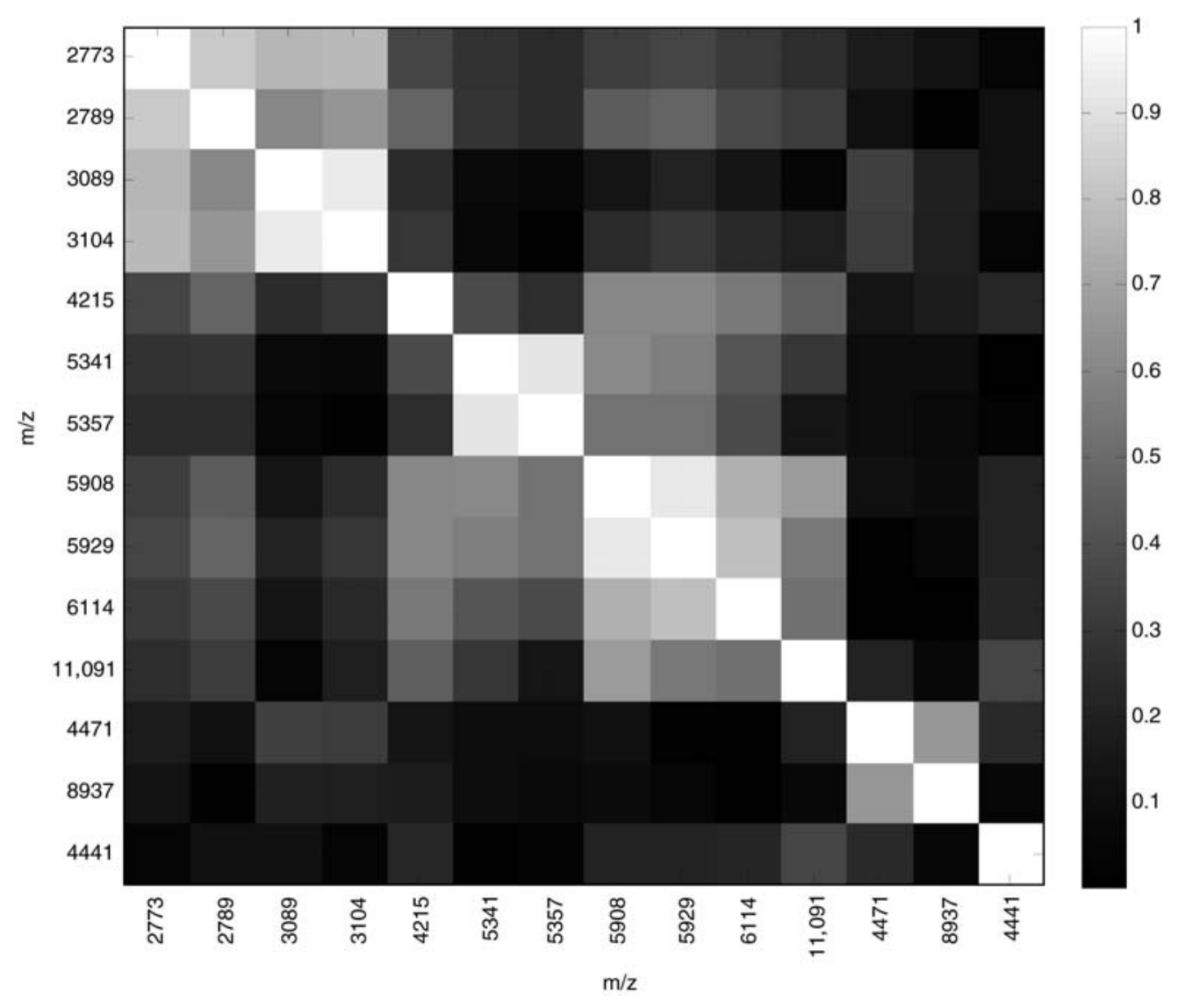

Figure 4 Peak intensity correlation matrix for the 14 peaks found to be associated with sample storage duration (for clarity, Pearson's correlation coefficients were converted into absolute values).

using SELDI-TOF MS. Of the 76 peak clusters detected throughout the spectrum, peak intensities of 14 peak clusters were found to be significantly associated with duration of sample storage. These were characterised by five different patterns (A-E). These peak clusters were structurally identified as $\mathrm{C} 3 \mathrm{a}_{\text {desArg }}$ and multiple fragments of albumin and fibrinogen. These proteins each appear to be associated with a distinct timedependent pattern, suggesting that every protein might have a unique time-dependent profile. Combining multiple samples by splitting the dataset into four categories of storage duration does not allow for investigation of time-dependent patterns within each individual sample. Thus, the observed patterns might actually be comprised of multiple patterns, but we only see the average. Our assumption that there is only one distribution of samples with respect to peptide levels and time dependence does, however, not affect our primary observation that the (SELDI-TOF MS) serum proteome is influenced by duration of sample storage.

The susceptibility of detected proteins to sample handling issues has been discussed in previous studies $(8,22,31)$. A number of these proteins have, however, also been reported as potential cancer markers $(10,11,21)$. Although not tumour-derived, it is currently hypothesised that these presumed cancer-specific serum proteins are generated from a pool of high-abundant founder proteins by tumour specific proteases $(11,32,33)$. Thus, these cleavage products were found to be specific for both disease and preanalytical sample handling parameters. Assessment of potential confounding pre-analytical parameters, such as storage time, is critical in order to prevent experimental variation to be interpreted erroneously as disease associated variation. Also, regarding the different non-linear patterns by which peak intensities were found associated to storage duration, simply applying linear corrections for sample storage duration may not suffice.

\section{The albumin clusters}

Four of the 14 significant peak clusters were observed to initially increase in peak intensity up to $\sim 5$ years of storage time, after which peak intensities decreased (Pattern A). Two clusters (m/z 3089 and $\mathrm{m} / \mathrm{z}$ 3104) were structurally identified as albumin fragments. The other two clusters (m/z 2773 and m/z 2789) most likely correspond to oxidised forms of the structurally identified m/z 2756 albumin fragment. We hypothesise that the observed pattern is the result of continuous in vitro proteolytic degradation of albumin and its fragments.

Albumin is the most abundant serum protein $(30-50 \mathrm{mg} / \mathrm{mL})$, comprising about one-half of serum proteins (34). Detection of its proteolytic fragments as markers for sample storage duration is therefore not unexpected. The susceptibility of albumin to proteolytic degradation during prolonged storage at $-30^{\circ} \mathrm{C}$ 


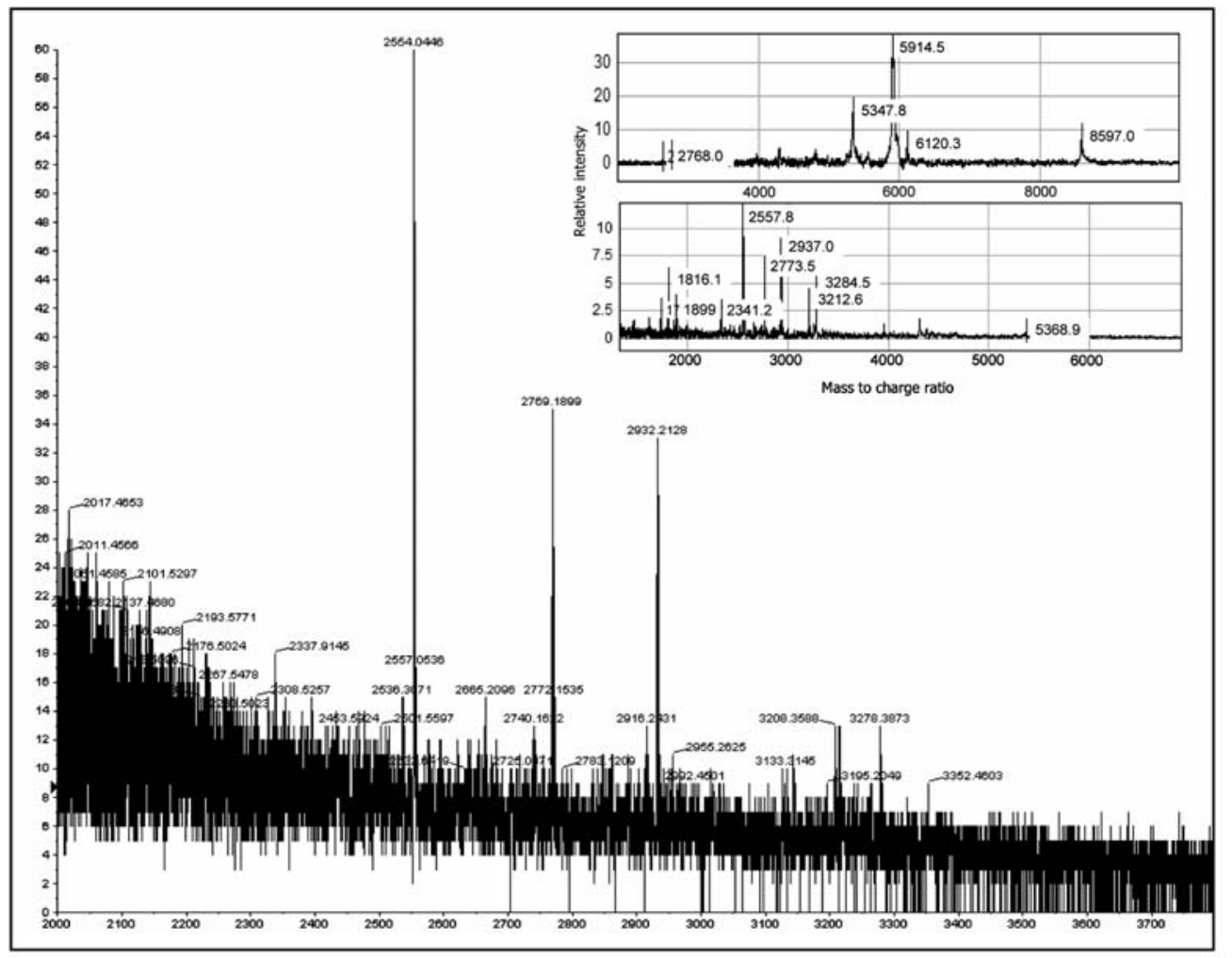

MASCOT peptide mapping results: $\quad$ m/z 5908 C-terminal fibrinogen fragment

\begin{tabular}{llllll}
\hline $\begin{array}{l}\text { Start- } \\
\text { End }\end{array}$ & $\begin{array}{l}\text { Mr } \\
\text { (obs) }\end{array}$ & $\begin{array}{l}\text { Mr } \\
\text { (expt) }\end{array}$ & $\begin{array}{l}\text { Mr } \\
\text { (calc) }\end{array}$ & Delta & Sequence \\
\hline $576-598$ & 2553.00 & 2551.99 & 2552.09 & -0.10 & K.SSSYSKQFTSSTSYNRGDSTFES.K \\
$576-600$ & 2768.20 & 2767.19 & 2767.22 & -0.03 & K.SSSYSKQFTSSTSYNRGDSTFESKS.Y \\
$576-601$ & 2931.20 & 2930.19 & 2930.28 & -0.09 & K.SSSYSKQFTSSTSYNRGDSTFESKSY.K \\
\hline Amino acid sequence of m/z 5341 C-terminal fibrinogen fragment (start: 576 - end: $625,53 \%$ sequence coverage): \\
SSSYSKQFTS STSYNRGDST FESKSYKMAD EAGSEADHEG THSTKRGHA \\
Amino acid Sequence of m/z 5908 C-terminal fibrinogen fragment (start: 576 - end: $630,48 \%$ sequence coverage): \\
SSSYSKQFTS STSYNRGDST FESKSYKMAD EAGSEADHEG THSTKRGHAK SRPV \\
\hline
\end{tabular}

Figure 5 Structural identification of the $\mathrm{m} / \mathrm{z} 5341$ and m/z 5908 peak clusters.

Direct sequencing of the $\mathrm{m} / \mathrm{z} 5341$ and $\mathrm{m} / \mathrm{z} 5908$ peak clusters. MS spectrum of the YM3 retentate. Insert: SELDI-TOF MS spectrum of the $50 \%$ ACN/0.1\% TFA RP18 eluate (upper spectrum) and YM3 retentate (lower spectrum). All peptides were sequenced with tandem MS using Q-TOF for confirmation. Results from the MASCOT search for protein identification include start and end positions of the peptide sequence starting from the amino acid terminal of the whole protein, the observed $\mathrm{m} / \mathrm{z}$ [Mr (obs)], transformed to its experimental mass [Mr (expt)], the calculated mass [Mr (calc)] from the matched peptide sequence, their mass difference (Delta), and the peptide sequence (in grey: the amino acid sequence determined by Q-TOF MS).

has been described previously by our group (22). We observed the N-terminal albumin ${ }_{25-57}$ fragment to be positively correlated with duration of storage (1.4 years) at $-30^{\circ} \mathrm{C}$. Similarly, peaks corresponding to our m/z 2773 and m/z 3104 peak clusters were also found to increase in peak intensity with increasing storage time.

\section{The fibrinogen clusters}

Seven of the 14 peak clusters found significantly associated with sample storage duration were identified as (probable) fibrinogen fragments. The $\mathrm{m} / \mathrm{z} 5908$ $\mathrm{FGA}_{576-630}$, its oxidised form at $\mathrm{m} / \mathrm{z} 5929$, its SPA adduct at $\mathrm{m} / \mathrm{z} 6114$, and the two alleged fibrinogen fragments at m/z 4215 and m/z 11,091 all continuously decreased in peak intensity with increasing sample storage time (Pattern B). The $\mathrm{m} / \mathrm{z} 5341 \mathrm{FGA}_{576-625}$ and its oxidised form at $\mathrm{m} / \mathrm{z} 5357$, however, decreased in peak intensity only after $\sim 6$ years of storage (Pattern E). These time-dependent changes in peak intensities represent the characteristics of a sequential process whereby fibrinogen fragments are proteolytically degraded into subsequent smaller fragments.

Fibrinogen acts as the primary factor in the formation of blood clots by polymerisation to a fibrin network and by enabling platelets to aggregate (35). Similar to albumin, it is one of the most abundant blood proteins $(2-4 \mathrm{mg} / \mathrm{mL})$. Thus, detection of proteolytic fibrinogen fragments by SELDI-TOF MS as indicators of sample storage duration is not surprising. In addition, various fibrinogen fragments have 


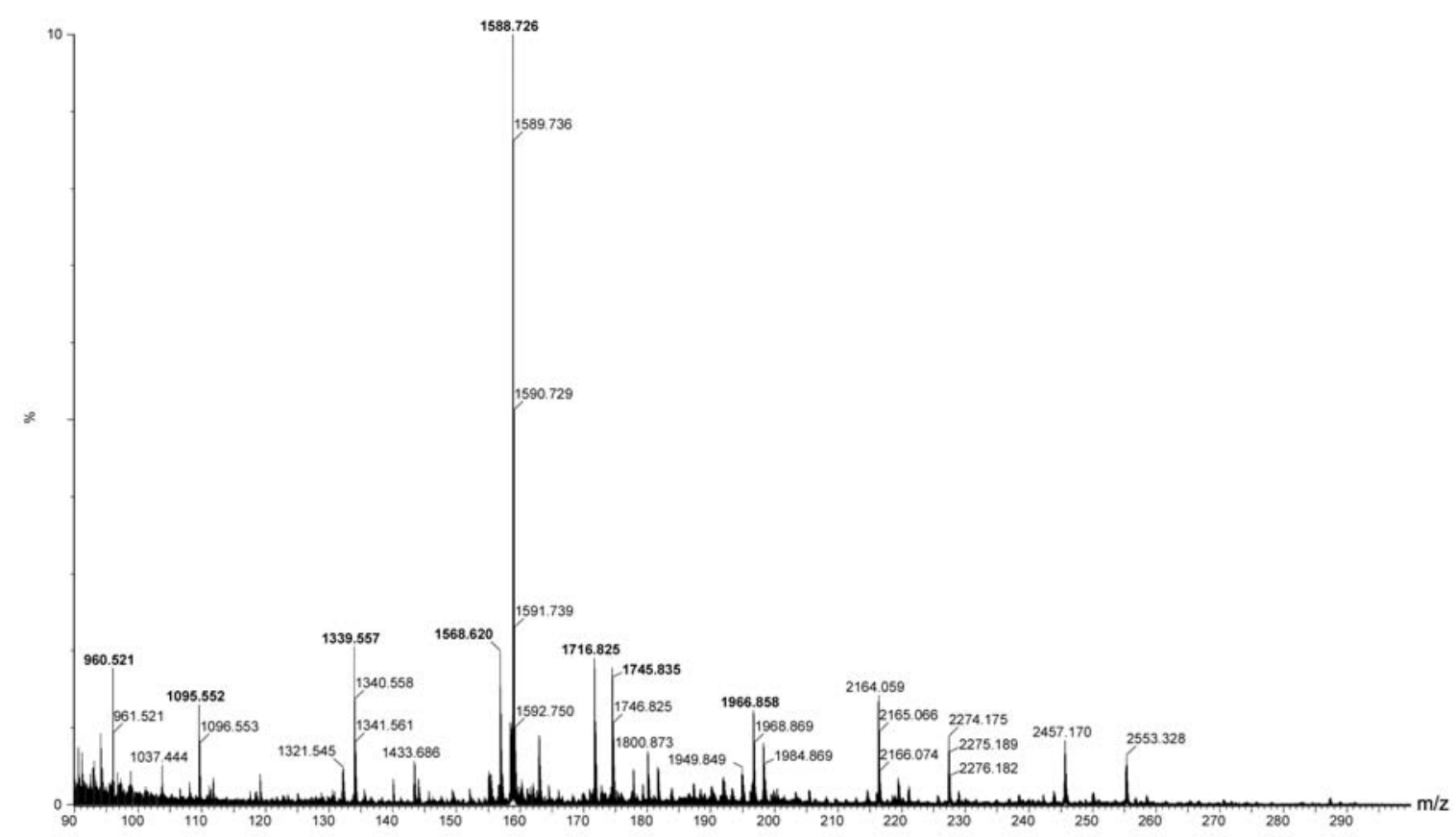

MASCOT peptide mapping results: $\quad$ m/z 8939 C3a desarg anaphylatoxin

\begin{tabular}{llllll}
\hline $\begin{array}{l}\text { Start- } \\
\text { End }\end{array}$ & $\begin{array}{l}\text { Mr } \\
\text { (obs) }\end{array}$ & $\begin{array}{l}\text { Mr } \\
\text { (expt) }\end{array}$ & $\begin{array}{l}\text { Mr } \\
\text { (calc) }\end{array}$ & Delta & Sequence \\
\hline $672-679$ & 960.52 & 959.51 & 959.54 & -0.03 & R.SVQLTEKR.M \\
$713-722$ & 1095.55 & 1094.54 & 1094.58 & -0.04 & R.FISLGEACKK.V \\
$699-709$ & 1339.59 & 1338.58 & 1338.58 & -0.00 & K.ELRKCCEDGMR.E \\
$692-704$ & 1568.64 & 1567.63 & 1567.64 & -0.00 & R.KCCEDGMRENPMR.F \\
$723-735$ & 1588.74 & 1587.73 & 1587.74 & -0.01 & K.VFLDCCNYITELR.R \\
$722-735$ & 1716.84 & 1715.83 & 1715.84 & -0.00 & K.KVFLDCCNYITELR.R \\
\hline
\end{tabular}

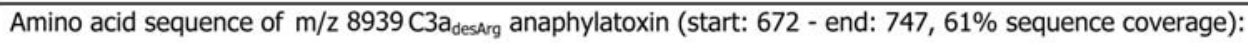
SVQLTEKRMD KVGKYPKELR KCCEDGMREN PMRFSCQRRT RFISLGEACK KVFLDCCNYI TELRRQHARA SHLGLA

Figure 6 Structural identification of the $\mathrm{m} / \mathrm{z} 8939$ peak cluster.

Peptide mapping of the $\mathrm{m} / \mathrm{z} 8939$ peak cluster. MS spectrum of the $\mathrm{m} / \mathrm{z} 8939$ tryptic digest in the gel eluate. All peptides were sequenced with tandem MS using Q-TOF for confirmation. Results from the MASCOT search for protein identification include start and end positions of the peptide sequence starting from the amino acid terminal of the whole protein, the observed $\mathrm{m} / \mathrm{z}$ [Mr (obs)], transformed to its experimental mass [Mr (expt)], the calculated mass [Mr (calc)] from the matched peptide sequence, their mass difference (Delta), the number of missed cleavage sites for trypsin (Miss), and the peptide sequence (in grey: the amino acid sequence determined by Q-TOF MS).

been found to be correlated with coagulation time. While the m/z 5908 FGA $_{576-630}$ continuously decreased in peak intensity with coagulation time, the intensities of all other peaks initially increased with coagulation time, and then either remained stable $(\mathrm{m} / \mathrm{z} 4215, \mathrm{~m} / \mathrm{z}$ $11,091)$, or decreased ( $\mathrm{m} / \mathrm{z} 5341, \mathrm{~m} / \mathrm{z} 6114)(8,31,36)$.

The different fibrinogen fragments have been described in relation to various types of cancer. Villanueva et al. (11) reported a decreased serum $\mathrm{m} / \mathrm{z}$ 5902 FGA $_{576-630}$ peak intensity in thyroid cancer compared to healthy individuals. In contrast, a $5.9 \mathrm{kDa}$ peak, not structurally identified, has been found increased in patients with colorectal $(37,38)$, pancreatic (39), gastric (40), and lung cancer $(41,42)$, and in hypopharyngeal squamous cell carcinoma (43). The latter two studies also reported increased serum $\mathrm{m} / \mathrm{z}$ 5339, 5927 and 6114 peak intensities in cancer cases compared with controls $(42,43)$. Although the sera of the groups compared in the above-mentioned studies allegedly were collected during the same time interval, accurate information on storage duration generally is not provided. Proteolytic degradation is, however, known to decrease with decreasing temperature. Since all sera investigated in these other studies were stored at $-80^{\circ} \mathrm{C}$, influence of storage duration on peak expression may be limited compared to our study performed on samples at $-30^{\circ} \mathrm{C}$. Regarding the allegedly improved protein stability at $-80^{\circ} \mathrm{C}$, future biomarker studies should investigate samples stored at $-80^{\circ} \mathrm{C}$. In addition, sample banks should attempt to maintain samples at $-80^{\circ} \mathrm{C}$.

\section{The $C 3 a_{\text {desArg }}$ clusters}

We observed two peak clusters at $\mathrm{m} / \mathrm{z} 8939$ and $\mathrm{m} / \mathrm{z}$ 4471, identified as $C 3 \mathrm{a}_{\text {desArg }}$ and its doubly charged form, to initially increase in peak intensity. After this initial increase intensities remained constant during 
the remaining time interval (Pattern D). The acute phase reactant $\mathrm{C} 3$ is the most abundant complement protein in serum, normally at a concentration of $1.2 \mathrm{mg} / \mathrm{mL}$ (44). This protein supports the activation of all three pathways of complement activation; the classic, alternative, and lectin pathway $(45,46)$. Produced primarily in the liver and adipocytes, it is formed by cleavage of C3 (185 kDa) by C3-convertases into C3b (176 kDa) and C3a (9 kDa) (47). The anaphylatoxin $\mathrm{C} 3 \mathrm{a}$ is short lived in serum, as carboxypeptidases cleave the $\mathrm{C}$-terminal arginine residue to create the more stable but biologically inactive $\mathrm{C} \mathrm{a}_{\text {desArg }}(8.9 \mathrm{kDa})(46-48)$. Presumably, the conversion of $\mathrm{C} 3 \mathrm{a}$ to $\mathrm{C} 3 \mathrm{a}_{\text {desArg }}$ becomes complete during the first months of storage, explaining the initial increase in $\mathrm{m} / \mathrm{z} 8939$ peak intensity. As m/z $8939 \mathrm{C} \mathrm{a}_{\text {desArg }}$ peak intensities remain stable following this increase, the protein appears not to be susceptible to proteolytic degradation; a finding that is corroborated by the reported stability of $\mathrm{C} 3 \mathrm{a}_{(\mathrm{des} A r g)}$ to extremes of heat and $\mathrm{pH}$ (49).

Complement can also be activated in vitro. Activation of the coagulation system is followed by activation of platelets, eliciting complement activation (50). Although not structurally identified, Banks et al. (8) reported that the intensity of an IMAC-Cu m/z 8939 and $\mathrm{m} / \mathrm{z} 4477$ peak significantly increased with prolonged coagulation times.

The $8.9 \mathrm{kDa} C 3 \mathrm{a}_{\text {desArg }}$ peak has been proposed as a biomarker in a number of studies investigating different cancer types using serum SELDI-TOF MS analysis $(21,51-54)$. This protein peak has been found increased in different cancers including breast $(18,21$, $24,55)$, colorectal $(51,54)$, hepatocellular $(52,56,57)$, and chronic lymphoid malignancies (53). In contrast, the studies of Hu et al. (58) and Han et al. (42) reported an $8.9 \mathrm{kDa}$ peak, not structurally identified, that was decreased in sera from patients with breast and lung cancer. Since information regarding sample collection interval is rarely provided in reported studies, the extent to which sample storage duration might have biased reported results cannot be assessed.

Of particular interest are two studies published by $\mathrm{Li}$ et al. $(18,21)$. Their first study reported an $8.9 \mathrm{kDa}$ peak that was increased in patients with breast cancer compared to healthy controls. This peak had a very high diagnostic utility (18). The sera from cancer patients were, however, collected over a longer time interval compared with control sera; the association between sample storage duration and peak expression was not investigated. The increase in the $8.9 \mathrm{kDa}$ peak, identified as $\mathrm{C} 3 \mathrm{a}_{\text {desArg, }}$ in breast cancer patients was confirmed by analysis of a second independent sample set. All sera were collected within the same 2-year time period. When compared with their initial study, the diagnostic performance of the $8.9 \mathrm{kDa}$ peak was much lower. This indicates probable bias due to duration of sample storage in their initial study (21). However, results of their initial study were indeed reproducible, as shown in their validation study. The sample set from their first study was stored at $-80^{\circ} \mathrm{C}$, a temperature at which the formation of $\mathrm{C} 3 \mathrm{a}_{\text {desArg }}$ might be limited when compared with storage at $-30^{\circ} \mathrm{C}$. The sample set for their validation study was stored at $-30^{\circ} \mathrm{C}$. However, since all their validation sera were obtained during the same time interval, the samples of this set are unlikely to be biased by duration of sample storage. Although results may be reproducible when samples of different groups differ in storage time, investigators still need to assess potential bias due to storage parameters. In addition, in order to prevent samples from different patient groups (i.e., cancer vs. control) being stored for different periods of time, biorepositories should collect matched case and control samples.

We have not yet structurally identified the last peak cluster at $\mathrm{m} / \mathrm{z} 4441$. This peak was found to be positively associated with sample storage duration. Most likely, this $\mathrm{m} / \mathrm{z} 4441$ cluster represents a high-abundant serum protein fragment, formed by continuous non-specific proteolytic activity during storage at $-30^{\circ} \mathrm{C}$.

In conclusion, we identified SELDI-TOF MS peak intensities of $\mathrm{C}^{3} \mathrm{a}_{\text {desArg }}$ and various albumin and fibrinogen fragments that were significantly associated with storage duration of sera from 140 patients with breast cancer. These proteins, however, have also been described as potential cancer markers, rendering them specific to both disease and sample handling issues. Thus, assessment of potential confounding pre-analytical parameters, such as sample storage time, should be an integral component of biomarker discovery and validation studies. This is necessary in order to prevent experimental variation to be interpreted erroneously as variation that is associated with disease. In addition, regarding the different (non-)linear patterns by which peak intensities were found to be associated with duration of sample storage, applying simple linear corrections to account for the duration of sample storage will not necessarily suffice.

\section{Acknowledgements}

This study was supported by a grant of the Dutch Cancer Society (project NKI 2005-3421).

\section{References}

1. Banks RE, Dunn MJ, Hochstrasser DF, Sanchez JC, Blackstock W, Pappin DJ, et al. Proteomics: new perspectives, new biomedical opportunities. Lancet 2000;356:174956.

2. Aebersold R, Anderson L, Caprioli R, Druker B, Hartwell L, Smith R. Perspective: a program to improve protein biomarker discovery for cancer. J Proteome Res 2005;4: 1104-9.

3. Dove A. Proteomics: translating genomics into products? Nat Biotechnol 1999;17:233-6.

4. Clarke W, Zhang Z, Chan DW. The application of clinical proteomics to cancer and other diseases. Clin Chem Lab Med 2003;41:1562-70.

5. Hutchens TW, Yip TT. New desorption strategies for the mass spectrometric analysis of macromolecules. Rapid Commun Mass Spectrom 1993;7:576-80. 
6. Issaq HJ, Veenstra TD, Conrads TP, Felschow D. The SELDI-TOF MS approach to proteomics: protein profiling and biomarker identification. Biochem Biophys Res Commun 2002;292:587-92.

7. Anderson NL, Anderson NG. The human plasma proteome: history, character, and diagnostic prospects. Mol Cell Proteomics 2002;1:845-67.

8. Banks RE, Stanley AJ, Cairns DA, Barrett JH, Clarke P, Thompson D, et al. Influences of blood sample processing on low-molecular-weight proteome identified by surface-enhanced laser desorption/ionization mass spectrometry. Clin Chem 2005;51:1637-49.

9. Zhang Z, Bast RC Jr, Yu Y, Li J, Sokoll LJ, Rai AJ, et al. Three biomarkers identified from serum proteomic analysis for the detection of early stage ovarian cancer. Cancer Res 2004;64:5882-90.

10. Engwegen JY, Helgason $\mathrm{HH}$, Cats A, Harris $\mathrm{N}$, Bonfrer JM, Schellens JH, et al. Identification of serum proteins discriminating colorectal cancer patients and healthy controls using surface-enhanced laser desorption ionisation-time of flight mass spectrometry. World J Gastroenterol 2006;12:1536-44.

11. Villanueva J, Martorella AJ, Lawlor K, Philip J, Fleisher M, Robbins RJ, et al. Serum peptidome patterns that distinguish metastatic thyroid carcinoma from cancer-free controls are unbiased by gender and age. Mol Cell Proteomics 2006;5:1840-52.

12. Ransohoff DF. Lessons from controversy: ovarian cancer screening and serum proteomics. J Natl Cancer Inst 2005;97:315-9.

13. Villanueva J, Philip J, Chaparro CA, Li Y, Toledo-Crow R, DeNoyer $L$, et al. Correcting common errors in identifying cancer-specific serum peptide signatures. J Proteome Res 2005;4:1060-72.

14. Findeisen $P$, Sismanidis D, RiedI M, Costina V, Neumaier M. Preanalytical impact of sample handling on proteome profiling experiments with matrix-assisted laser desorption/ionization time-of-flight mass spectrometry. Clin Chem 2005;51:2409-11.

15. Albrethsen J, Bogebo R, Olsen J, Raskov H, Gammeltoft S. Preanalytical and analytical variation of surfaceenhanced laser desorption-ionization time-of-flight mass spectrometry of human serum. Clin Chem Lab Med 2006;44:1243-52.

16. Hsieh SY, Chen RK, Pan YH, Lee HL. Systematical evaluation of the effects of sample collection procedures on low-molecular-weight serum/plasma proteome profiling. Proteomics 2006;6:3189-98.

17. Rai AJ, Gelfand CA, Haywood BC, Warunek DJ, Yi J, Schuchard MD, et al. HUPO plasma proteome project specimen collection and handling: towards the standardization of parameters for plasma proteome samples. Proteomics 2005;5:3262-77.

18. Li J, Zhang Z, Rosenzweig J, Wang YY, Chan DW. Proteomics and bioinformatics approaches for identification of serum biomarkers to detect breast cancer. Clin Chem 2002;48:1296-304

19. Belluco C, Petricoin EF, Mammano E, Facchiano F, RossRucker S, Nitti D, et al. Serum proteomic analysis identifies a highly sensitive and specific discriminatory pattern in stage 1 breast cancer. Ann Surg Oncol 2007; 14:2470-6.

20. Adam BL, Qu Y, Davis JW, Ward MD, Clements MA, Cazares $\mathrm{LH}$, et al. Serum protein fingerprinting coupled with a pattern-matching algorithm distinguishes prostate cancer from benign prostate hyperplasia and healthy men. Cancer Res 2002;62:3609-14.

21. Li J, Orlandi R, White CN, Rosenzweig J, Zhao J, Seregni $\mathrm{E}$, et al. Independent validation of candidate breast cancer serum biomarkers identified by mass spectrometry. Clin Chem 2005;51:2229-35.
22. Engwegen JY, Alberts $M$, Knol JC, Jimenez CR, Depla $A C$, Tuynman $H$, et al. Influence of variations in sample handling on SELDI-TOF MS serum protein profiles for colorectal cancer. Proteomics Clin Appl 2008;2: 936-45.

23. McLerran D, Grizzle WE, Feng Z, Bigbee WL, Banez LL, Cazares $\mathrm{LH}$, et al. Analytical validation of serum proteomic profiling for diagnosis of prostate cancer; sources of sample bias. Clin Chem 2007;54:44-52.

24. Mathelin C, Cromer A, Wendling C, Tomasetto C, Rio MC. Serum biomarkers for detection of breast cancers: a prospective study. Breast Cancer Res Treat 2005;1-8.

25. Becker S, Cazares LH, Watson P, Lynch H, Semmes OJ, Drake RR, et al. Surfaced-enhanced laser desorption/ionization time-of-flight (SELDI-TOF) differentiation of serum protein profiles of BRCA-1 and sporadic breast cancer. Ann Surg Oncol 2004;11:907-14.

26. Laronga C, Becker S, Watson P, Gregory B, Cazares L, Lynch $\mathrm{H}$, et al. SELDI-TOF serum profiling for prognostic and diagnostic classification of breast cancers. Dis Markers 2003;19:229-38.

27. Vlahou A, Laronga C, Wilson L, Gregory B, Fournier K, McGaughey D, et al. A novel approach toward development of a rapid blood test for breast cancer. Clin Breast Cancer 2003;4:203-9.

28. Goncalves A, Esterni B, Bertucci F, Sauvan R, Chabannon $\mathrm{C}$, Cubizolles $\mathrm{M}$, et al. Postoperative serum proteomic profiles may predict metastatic relapse in high-risk primary breast cancer patients receiving adjuvant chemotherapy. Oncogene 2006;25:981-9.

29. Karsan A, Eigl BJ, Flibotte S, Gelmon K, Switzer P, Hassell $P$, et al. Analytical and preanalytical biases in serum proteomic pattern analysis for breast cancer diagnosis. Clin Chem 2005;51:1525-8.

30. Hu J, Coombes KR, Morris JS, Baggerly KA. The importance of experimental design in proteomic mass spectrometry experiments: some cautionary tales. Brief Funct Genomic Proteomic 2005;3:322-31.

31. Baumann S, Ceglarek U, Fiedler GM, Lembcke J, Leichtle A, Thiery J. Standardized approach to proteome profiling of human serum based on magnetic bead separation and matrix-assisted laser desorption/ionization time-offlight mass spectrometry. Clin Chem 2005;51:973-80.

32. Fung ET, Yip TT, Lomas L, Wang Z, Yip C, Meng XY, et al. Classification of cancer types by measuring variants of host response proteins using SELDI serum assays. Int J Cancer 2005;115:783-9.

33. Villanueva J, Shaffer DR, Philip J, Chaparro CA, Erdjument-Bromage $H$, Olshen $A B$, et al. Differential exoprotease activities confer tumor-specific serum peptidome patterns. J Clin Invest 2006;116:271-84.

34. Quinlan GJ, Martin GS, Evans TW. Albumin: biochemical properties and therapeutic potential. Hepatology 2005; 41:1211-9.

35. Mosesson MW. Fibrinogen and fibrin structure and functions. J Thromb Haemost 2005;3:1894-904.

36. Timms JF, Arslan-Low E, Gentry-Maharaj A, Luo Z, T'Jampens D, Podust VN, et al. Preanalytic influence of sample handling on SELDI-TOF serum protein profiles. Clin Chem 2007;53:645-56.

37. Chen YD, Zheng S, Yu JK, Hu X. Artificial neural networks analysis of surface-enhanced laser desorption/ ionization mass spectra of serum protein pattern distinguishes colorectal cancer from healthy population. Clin Cancer Res 2004;10:8380-5.

38. Yu JK, Chen YD, Zheng S. An integrated approach to the detection of colorectal cancer utilizing proteomics and bioinformatics. World J Gastroenterol 2004;10:3127-31.

39. Koopmann J, Zhang Z, White N, Rosenzweig J, Fedarko $N$, Jagannath $S$, et al. Serum diagnosis of pancreatic 
adenocarcinoma using surface-enhanced laser desorption and ionization mass spectrometry. Clin Cancer Res 2004;10:860-8.

40. Liang Y, Fang M, Li J, Liu CB, Rudd JA, Kung HF, et al. Serum proteomic patterns for gastric lesions as revealed by SELDI mass spectrometry. Exp Mol Pathol 2006; 81:176-80.

41. Xiao X, Liu D, Tang Y, Guo F, Xia L, Liu J, et al. Development of proteomic patterns for detecting lung cancer. Dis Markers 2003;19:33-9.

42. Han KQ, Huang G, Gao CF, Wang XL, Ma B, Sun LQ, et al. Identification of lung cancer patients by serum protein profiling using surface-enhanced laser desorption/ ionization time-of-flight mass spectrometry. Am J Clin Oncol 2008;31:133-9.

43. Zhou L, Cheng L, Tao L, Jia X, Lu Y, Liao P. Detection of hypopharyngeal squamous cell carcinoma using serum proteomics. Acta Otolaryngol 2006;126:853-60.

44. Hugli TE. Human anaphylatoxin (C3a) from the third component of complement. Primary structure. J Biol Chem 1975;250:8293-301.

45. Bohana-Kashtan O, Ziporen L, Donin N, Kraus S, Fishelson Z. Cell signals transduced by complement. Mol Immunol 2004;41:583-97.

46. Sahu A, Sunyer JO, Moore WT, Sarrias MR, Soulika AM, Lambris JD. Structure, functions, and evolution of the third complement component and viral molecular mimicry. Immunol Res 1998;17:109-21.

47. de Bruijn $\mathrm{MH}$, Fey GH. Human complement component C3: cDNA coding sequence and derived primary structure. Proc Natl Acad Sci USA 1985;82:708-12.

48. Nettesheim DG, Edalji RP, Mollison KW, Greer J, Zuiderweg ER. Secondary structure of complement component C3a anaphylatoxin in solution as determined by NMR spectroscopy: differences between crystal and solution conformations. Proc Natl Acad Sci USA 1988; 85:5036-40.

49. Hugli TE, Morgan WT, Muller-Eberhard HJ. Circular dichroism of $\mathrm{C} 3 \mathrm{a}$ anaphylatoxin. Effects of $\mathrm{pH}$, heat, gua- nidinium chloride, and mercaptoethanol on conformation and function. J Biol Chem 1975;250:1479-83.

50. Hamad OA, Ekdahl K, Lambris JD, Nilsson B. Complement activation triggered by thrombin receptor-activated platelets. Mol Immunol 2007;44:180.

51. Habermann JK, Roblick UJ, Luke BT, Prieto DA, Finlay WJ, Podust VN, et al. Increased serum levels of complement C3a anaphylatoxin indicate the presence of colorectal tumors. Gastroenterology 2006;131:1020-9.

52. Lee IN, Chen CH, Sheu JC, Lee HS, Huang GT, Chen DS, et al. Identification of complement $\mathrm{C} 3 \mathrm{a}$ as a candidate biomarker in human chronic hepatitis $\mathrm{C}$ and $\mathrm{HCV}$-related hepatocellular carcinoma using a proteomics approach. Proteomics 2006;6:2865-73.

53. Miguet $L$, Bogumil R, Decloquement $P$, Herbrecht $R$, Potier N, Mauvieux L, et al. Discovery and identification of potential biomarkers in a prospective study of chronic lymphoid malignancies using SELDI-TOF-MS. J Proteome Res 2006;5:2258-69.

54. Ward DG, Suggett N, Cheng Y, Wei W, Johnson H, Billingham LJ, et al. Identification of serum biomarkers for colon cancer by proteomic analysis. Br J Cancer 2006; 94:1898-905.

55. Pusztai L, Gregory BW, Baggerly KA, Peng B, Koomen J, Kuerer HM, et al. Pharmacoproteomic analysis of prechemotherapy and postchemotherapy plasma samples from patients receiving neoadjuvant or adjuvant chemotherapy for breast carcinoma. Cancer 2004;100: 1814-22.

56. Poon TC, Yip TT, Chan AT, Yip C, Yip V, Mok TS, et al. Comprehensive proteomic profiling identifies serum proteomic signatures for detection of hepatocellular carcinoma and its subtypes. Clin Chem 2003;49:752-60.

57. Schwegler EE, Cazares L, Steel LF, Adam BL, Johnson DA, Semmes OJ, et al. SELDI-TOF MS profiling of serum for detection of the progression of chronic hepatitis $C$ to hepatocellular carcinoma. Hepatology 2005;41:634-42.

58. Hu Y, Zhang S, Yu J, Liu J, Zheng S. SELDI-TOF-MS: the proteomics and bioinformatics approaches in the diagnosis of breast cancer. Breast 2005;14:250-5. 